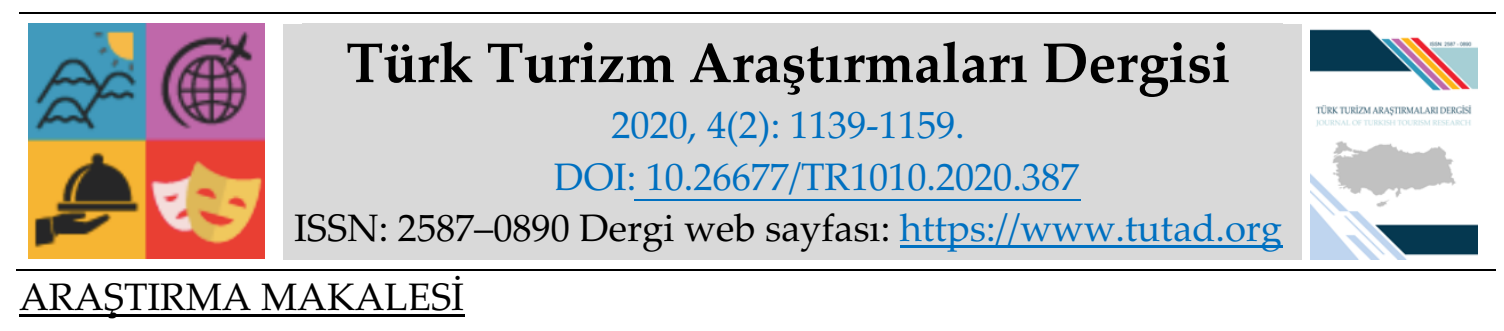

\title{
Boş Zaman ve Rekreasyon Konulu Tezler Üzerine Bibliyometrik Bir Çalışma
}

Sezer YERSÜREN, Doktora Öğrencisi, Anadolu Üniversitesi, Sosyal Bilimler Enstitüsü, Eskişehir, e-posta: sezeryersuren@gmail.com

ORCID: https://orcid.org/0000-0001-7511-5345

Doç. Dr. Çağıl Hale ÖZEL, Anadolu Üniversitesi, Turizm Fakültesi, Eskişehir, e-posta: chkayar@anadolu.edu.tr

ORCID: https://orcid.org/0000-0002-4898-0867

Öz

$\mathrm{Bu}$ çalışma boş zaman ve rekreasyon alanında Türkiye'de hazırlanan lisansüstü tezleri bibliyometrik özellikler çerçevesinde değerlendirmek amacıyla gerçekleştirilmiştir. Araştırma kapsamında 1987-2019 yılları arasında Türkiye'de yayımlanan lisansüstü tezler incelenmiştir. Verilere Yükseköğretim Kurulu Ulusal Tez Merkezi (YÖKTEZ) veri tabanından 24-25.10.2019 tarihlerinde ulaşılmıştır. Tezler "rekreasyon, boş zaman ve serbest zaman" anahtar kelimeleriyle taranmış ve çalışmaya ulaşılabilen 536 lisansüstü tez dahil edilmiştir. Araştırmaya dahil edilen tezler, "yayımlandığı yıl, tezin türü, anahtar kelimeler, anabilim dalı, uygulanan araştırma yöntemi, veri analiz tekniği, alt boyutlar ve ilişkilendirilen kavramlar" parametreleri çerçevesinde değerlendirilmiştir. Çalışmaya konu olan verilerin analizinde yüzde ve sıklık dağılımları incelenmiş; bibliyometrik analizlerden yararlanılmıştır. Analiz sonucunda beden eğitimi ve spor bilimleri, rekreasyon, peyzaj mimarlığı ve turizm anabilim dallarında gerçekleştirilen rekreasyon ve boş zamana ilişkin lisansüstü tezlerin sayısının diğer anabilim dallarına göre daha fazla olduğu tespit edilmiştir. Lisansüstü tezlerin rekreasyon faaliyetleri ve rekreasyonel etkinlikler alt boyutunda yoğunlaştıkları gözlemlenmiştir. Ayrıca, rekreasyon ve boş zaman kavramlarının sıklıkla turizm, spor ve peyzaj kavramlarıyla ilişkilendirilerek incelendiği sonucuna ulaşılmıştır.

Anahtar Kelimeler: Boş Zaman, Serbest Zaman, Rekreasyon, Lisansüstü Eğitim, Bibliyometri.

Makale Gönderme Tarihi: 18.02 .2020

Makale Kabul Tarihi: 12.04 .2020

\footnotetext{
Önerilen Atıf:

Yersüren, S. ve Özel, Ç. H. (2020). Boş Zaman ve Rekreasyon Konulu Tezler Üzerine Bibliyometrik Bir Çalışma, Türk Turizm Araştırmaları Dergisi, 4(2): 1139-1159.

(C) 2020 Türk Turizm Araştırmaları Dergisi.
} 


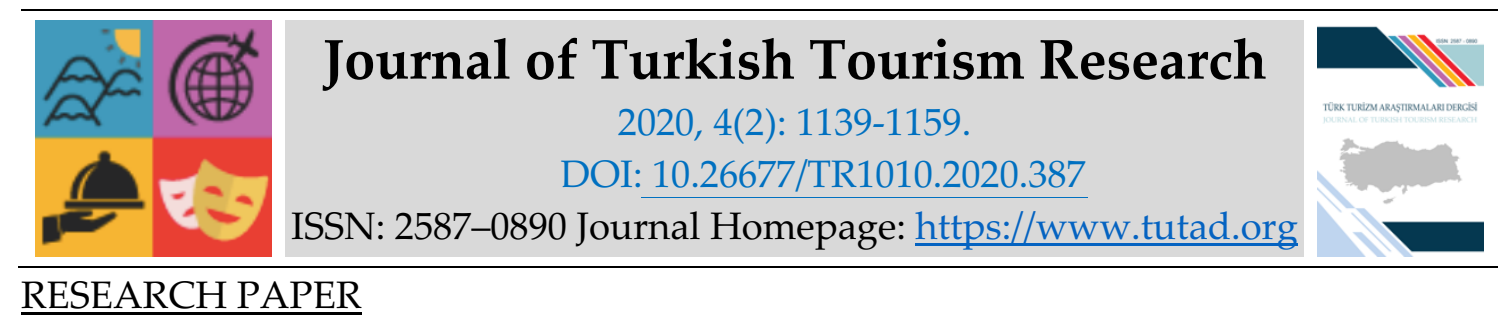

\title{
A Bibliometric Study on Theses on Leisure and Recreation
}

Sezer YERSÜREN, Ph.D. Student, Anadolu University, Social Sciences Institute, Eskişehir, e-mail: sezeryersuren@gmail.com ORCID: https://orcid.org/0000-0001-7511-5345

Associate Prof. Dr. Çağıl Hale ÖZEL, Anadolu University, Faculty of Tourism, Eskişehir, email:chkayar@anadolu.edu.tr ORCID: https://orcid.org/0000-0002-4898-0867

\begin{abstract}
This study was carried out in order to evaluate the framework of the bibliometric characteristics of graduate theses in the field of leisure and recreation prepared in Turkey. Within the context of the research, graduate theses published in Turkey between 1987-2019 were examined. The data were obtained from the National Thesis Center (YÖKTEZ) database of the Higher Education Council on 24-25.10.2019. Theses were scanned with the keywords "recreation", "leisure", "leisure time" and 536 graduate theses were included in the study. Theses included in the research were evaluated within the framework of parameters of "the year of publication, type of thesis, keywords, department, applied research method, data analysis technique, sub-dimensions and related concepts". Distributions of percentage and frequency were analyzed in the analysis of the subject data; bibliometric analyses were used. As a result of the analysis, it is determined that the number of graduate theses related to recreation and leisure in physical education and sports sciences, recreation, landscape architecture and tourism departments are higher than other departments. It is observed that graduate theses are concentrated in recreation activities and recreational activities sub-dimension. In addition, it is concluded that recreation and leisure concepts are frequently examined as associated with the concepts of tourism, sports and landscape.
\end{abstract}

Keywords: Leisure, Leisure Time, Recreation, Graduate Education, Bibliometry.

Received: 18.02 .2020

Accepted: 12.04 .2020

Suggested Citation:

Yersüren, S. and Özel, Ç. H. (2020). A Bibliometric Study on Theses on Leisure and Recreation, Journal of Turkish Tourism Research, 4(2): 1139-1159.

(C) 2020 Türk Turizm Araştırmaları Dergisi. 


\section{GİRIŞ}

Tarihsel süreçte insanların yerleşik hayata geçmeleriyle birlikte tarımsal faaliyetler gerçekleştirilmeye başlanmış; insanlar kendi üstlerine düşen tarım işlerini yerine getirdikten sonra arda kalan bir zamana sahip olmuşlardır. Burada boş zamanın kazanımı, işin bitme süresiyle yakından ilişkilidir. Her işçi ne kadar kısa sürede işini bitirirse o kadar fazla boş zamana sahip olmuştur. Dolayısıyla, boş zaman o dönemde bireysel özellik taşımıştır. Ancak Sanayi Devrimi ile birlikte gelen kitlesel üretim, işçilerin daha fazla çalışmasını gerektirmiştir. İşçiler ise olumsuz çalışma şartlarına tepki olarak gerçekleştirdikleri sendikal hareketler sayesinde hak ve özgürlükler kazanmıştır. Böylece işçiler yasalarla korunmuş, çalıştıkları zaman dışında kalan bir zamana sahip olmuşlardır. Bu kez, boş zaman kazanımı, işçilerin hafta sonu tatil günlerinde, resmi tatil günlerinde ve çalışma saatleri dışında kalan zamanlarındaki boş zaman olarak görülmüştür. Tüm işçilerin aynı zaman diliminde boş zamana sahip olması ise boş zamanın sanayi devrimi sonrasında kitlesel bir niteliğe dönüşmesi sonucunu beraberinde getirmiştir.

İnsanların sahip olduğu boş zaman haklarının değerlendirilebilmesi açısından boş zaman hizmetleri sunan bir endüstrinin oluşmaya başlaması, Sanayi Devrimi sonrasına tarihlenir. Zamanla boş zamanın değerlendirilmesine ilişkin ilginin ve boş zamanın öneminin arttığını belirtmek mümkündür. Boş zamanın değerlendirilmesi, yönetilmesi, planlanması, eğitiminin verilmesi açısından profesyonellere ihtiyaç duyulmuştur. Bu ihtiyacın giderilmesi konusunda boş zaman ve rekreasyon alanına ilişkin çalışmalara yoğunlaşıldığı ve lisansüstü eğitimde rekreasyon bölümlerinin açılmaya başlandığı görülmektedir. İlk olarak Amerika Birleşik Devletleri'nde açılan rekreasyon bölümleri ve gerçekleştirilen rekreasyon araştırmaları ile bu alana dair bir eğilim oluşmuştur. Zamanla rekreasyon kavramı gelişmeye, bilimsel çalışmaların çoğalmasıyla birlikte bu alan olgunlaşmaya başlamıştır.

Bilimsel bir alanın incelenmesinde olduğu gibi rekreasyon alanının da mevcut durumunu, gelişimini doğru anlayabilmek ve sorunların çözümleyebilmek için incelenmesi, önemlilik arz eder (Kozak, 1994). Bu sayede, çalışılan alanın portresi oluşturulur; teorik, kuramsal ve kavramsal durumu belirlenir ve durum değerlendirmesinin yapılmasına olanak tanınır. Bu kapsamda rekreasyon ve boş zaman çalışmalarında yararlanılan araştırma yöntemleri, boş zaman ve rekreasyon kavramlarının alt boyutları ve ilişkilendirilen kavramları gibi parametreler açısından değerlendirilmesi ile o alanda ne tür gelişmelerin oluştuğu, alanın nasıl ve ne yönde ilerlediği görülebilmektedir. $\mathrm{Bu}$ tür bir inceleme ayrıca yeni yöntemlerin ve tekniklerin gelişmesine zemin hazırlar ve gelecekteki çalışmalara da 1şık tutar. Bu incelemenin yapılabilmesinde bibliyometriden yararlanılmaktadır.

Bibliyometri, sayım yapmaya dayalı bir inceleme alanıdır. Bibliyometrik araştırmalar, belgelerin ya da yayınların belirli özelliklerinin analiz edilmesi ve bilimsel iletişime ilişkin çeşitli bulguların elde edilmesi esasına dayanmaktadır (Al ve Coştur, 2007: 144). Günümüzde bibliyometriye, yayınların ve atıf verilerinin niceliksel olarak incelenmesi ve ilgili alandaki gelişmelerin görülebilmesi için başvurulmaktadır. Bibliyometrik analizler sayesinde çalışılan alanın detaylı bir incelemesi yapılabilir. Böylece o alanın profili ortaya çıkarılarak gelişimine katkı sunulabilir. Bibliyometrinin turizm alanında gerçekleştirilen araştırmalardaki önemi de giderek artmaktadır. Turizmin bir bilgi alanı olarak genişlemesi ve bu konuda yayın yapan araştırmacıların sayıca artmasının bu konuda etken bir rol üstlendiği (Hall, 2011, Özel ve Kozak, 2012 ve Baytok vd., 2019) söylenmektedir. Bu çalışmada da Türkiye'de rekreasyon ve boş zaman alanına ilişkin lisansüstü tezlerin incelenmesi amaçlanmıştır. Bu sayede boş zaman ve rekreasyon alanının farklı bakış açılarıyla incelenmesine olanak sağlanabilir; alanın teorik ve pratik anlamda ilerlemesine katkı sunulabilir. 


\section{Boş Zaman ve Rekreasyon Eğitimi}

Boş zamanın, endüstriyel dönem öncesinde göçebe olarak yaşayan insanların yerleşik hayata geçmelerinden sonra ortaya çıtı̆̆̆ ifade edilir (Bull vd., 2003). Tarımla uğraşılan bu dönemde boş zamanın daha çok bireysel özellik taşıdığı görülmektedir. Ancak bu durum, Sanayi Devrimi ile birlikte değişmiştir. Bu gelişmeyi takiben çalışma hayatının daha kuralcı ve kitlesel bir hal aldığı söylenebilir. Bu baskıcı dönemin bir ürünü olan sendikal hareketlerin iş görenlerin hak ve özgürlüklerinde iyileşmeler sağlamasıyla birlikte boş zaman, iş ve iş dışı alan olarak nitelendirilmeye başlanmıştır. Boş zaman edinimi sayesinde çalışanların verimliliklerinde artış meydana geldiği, bu nedenle devletlerin ve kapitalist sistem uygulayıcılarının çalışanlara boş zaman hakkını planlı bir şekilde sağlamaya başladığı gözlemlenmektedir. Böylece boş zaman kavramı, bireyin kendini gerçekleştirebileceği bir alan olarak tanımlanmaya başlamıştır (Shivers ve DeLisle, 1997).

I. Dünya Savaşı sonrasında 1929 yılında Amerika'da meydana gelen ekonomik kriz sonrası, Amerikan hükümeti insanlara iş imkanları yaratmıştır. Hükümet, işten kalan zamanlarını değerlendirebilmeleri ve morallerini yükseltebilmeleri adına halka, rekreasyon tesisleri ve boş zaman değerlendirme hizmetleri sunmuştur. Böylece boş zamanın bugünkü anlamda örgütlü bir şekilde gelişmesinin önünün açıldığı ve boş zamanın olgunlaştığı söylenebilir (Currel, 2005). 19. yüzyıl itibariyle süregelen sanayileşme, kentleşme, küreselleşme, teknolojik ilerlemeler ve sosyokültürel değişimler ile boş zaman yeni bir anlam kazanmaya başlamıştır. Bu durum eğlence, dinlence ve kişiyi özgür kılma gibi etkenlerin oluşabilmesi adına gerekli zamanın yaratılmasına olanak tanımıştır (Sağcan, 1986; Godbey vd., 2005). Bu gelişmeler ile birlikte boş zaman, paydaşlarca (toplum, hükümetler, işletmeler) bireyin sahip olması gereken bir hak olarak görülmeye başlanmıştır (Shivers ve DeLisle, 1997 ve Metin, 2013: 11). Elde edilen boş zaman hakkı ile çalışanlar, iş dışı zamanlarını daha faal bir şekilde değerlendirmeye başlamışlardır. Bunun bir sonucu olarak çalışanlar, rekreasyon ve boş zaman hizmetlerine ve işletmelerine ihtiyaç duymuştur. Bu alana ilişkin kamusal alandaki ve özel sektördeki uygulamalar hızla yaygınlaştığından yeni iş alanları ortaya çıkmakta, nitelikli elemana ihtiyaç duyulmaktadır. Bu ihtiyacın karşılanmasında en büyük katkıyı, eğitim kurumları sağlamaktadır. Rekreasyon ve boş zaman alanındaki eğitim kurumlarının doğru bir şekilde yapılandırılması, nitelikli personelin yetiştirilmesinde ve akademik katkıların artırılmasında kolaylık sağlayacaktır. Böylece hem boş zaman ve rekreasyon sektörüne hem de boş zaman ve rekreasyon akademisine ilişkin profesyonellerin yetiştirilmesi sağlanabilir.

Boş zaman ve rekreasyon eğitiminin önemli aşamalarından biri, lisansüstü eğitim aşamasıdır. Lisansüstü eğitim, bir ülkenin geleceğinde söz sahibi olacak bilim insanlarının, akademisyenlerin ve üst düzey yöneticilerin yetiştirilmesine katkı sağlayan eğitim sürecidir (Sevinç, 2001: 125). 2547 sayılı Yükseköğretim Kanunu'na göre lisansüstü eğitim, yüksek lisans, doktora, tıpta uzmanlık ve sanatta yeterlik eğitimini kapsar. Lisansüstü eğitim, bilim/sanat üretmek ve yaymak, toplumsal sorunları doğru anlamak ve çözüm üretmek, üst düzey insan gücü yetiştirmek konusunda rol oynamayı hedeflemektedir. Ayrıca tez/sanat eseri çalışmaları, bilim ve sanat üretimine temel oluşturur. Lisansüstü eğitim döneminde gerçekleştirilen çalışmalar, bir bilim alanının akademik olarak gelişmesinde ve ilerlemesinde önemli bir rol üstlenmektedir. Her alanda olduğu gibi rekreasyon ve boş zaman alanında da bilimsel çalışmalar yürütülmektedir. Dolayısıyla rekreasyon kavraminın algılanmasında ve uygulamada kullanılmasında akademik gelişmeler yaşandığı söylenebilir. Bu gelişmeler, boş zaman, rekreasyon ve ilişkili bölümlerin açılmasında da önemli bir rol üstlenmiştir (Tütüncü, 2008: 93- 95 ve Çetinkaya, 2011: 14-16).

Rekreasyon ve boş zaman ile ilgili bölümlerin 1920'lerde Amerika Birleşik Devletleri'nde açıldığ belirtilmektedir. Amerikan Ulusal Rekreasyon Kurumu (NRPA) profesyonel rekreasyon, park ve 
boş zaman liderleri yetiştirmek için bir eğitim programı geliştirmiştir (Metin, 2012: 151'den aktaran; Kızanlıklı, 2014: 49). Bu programa ilişkin eğitim müfredatı, 1940’lı yıllarda Kuzey Amerika'daki üniversitelerde yer almaya başlamıştır. Burada tek bölüm içinde hem boş zaman çalışmalarına hem de rekreasyon ve park yönetimine yer verildiği görülmektedir. Amerikan Rekreasyon Birliği'nin Mesleki Eğitim Birimi ise 1950'lerin sonlarında üniversite ve kolejlerde rekreasyon ve park eğitimi ile ilgili araştırmalarda bulunmaya başlamıştır. 1965-1975 yıllarında yüksek öğretimde rekreasyon alanındaki mesleki programlar, yoğun bir gelişme sürecine girmiştir (Stein, 1984: 338 ve Grant, 1984'ten aktaran; Kızanlıklı, 2014). Böylece rekreasyon alanının akademik eğitim içinde yer almaya başladığını söylemek mümkündür. Başta Amerika ve Kanada olmak üzere pek çok ülkede rekreasyon odaklı çok sayıda sertifika, lisans ve lisansüstü eğitim programı bulunmaktadır. Özellikle son 25 yıldır rekreasyon ve boş zaman çalışmalarının olgunlaştığı görülmektedir. 1991 yılında hazırlanan "Uluslararası Boş Zaman, Rekreasyon ve Benzer Alanlardaki Akademik Kurumlar Rehberi" listesine göre dünyada 60 ülkede rekreasyon alanına ilişkin 1400 kurumda eğitim verilmektedir (Rojek vd., 2006: 1). Türkiye'de ise rekreasyon alanı kapsamında 183 kurum olduğu tespit edilmiştir (Lapa vd., 2018: 89). Dünya genelinde sayıları hızla artan rekreasyon bölümlerinin ve anabilim dallarının, ağırlıklı olarak üniversitelerin "Sağlık Bilimleri Fakültelerinde (Uygulamalı Sağlık Bilimleri ya da Sağlık Meslek Fakülteleri gibi), Spor Teknolojisi Yüksek Okullarında (Sağlık, Rekreasyon, Park ya da Beden Eğitimi ve Spor Yüksek Okulları gibi) ve Turizm ve Ağırlama İşletmeciliği Yüksek okullarında (Turizm, Rekreasyon, Park ya da Turizm İşletmeciliği Yüksek Okulları)" yer aldığı görülmektedir (Tütüncü, 2008).

Türkiye'de rekreasyon eğitimine yönelik ilk atılımların kalkınma planlarında yer aldığ görülmektedir. Bu alandaki çalışmaların Altıncı Beş Yıllık Kalkınma Planı'nda (1990-1994) belirtilen "Boş zamanların değerlendirilmesinde eğitim ve organizasyon faaliyetlerini yürütecek nitelikli elemanların yetiştirilebilmesi amacı ile üniversitelerin beden eğitimi ve spor bölümlerinde "rekreasyon" anabilim dalı açılacaktır" ifadesi (Kalkınma Bakanlı̆̆ı, 2015a) ve Yedinci Beş Yıllık Kalkınma Planı́ndaki (1996-2000) “Boş zamanların değerlendirilmesinde eğitim ve organizasyon faaliyetlerini yürütecek insan gücünün yetiştirilmesi amaciyla üniversitelerde rekreasyon ana bilim dalı tesis edilecektir" ifadesinden hareketle başladığ 1 söylenebilir (Kalkınma Bakanlığı, 2015b). Üniversitelerarası Kurul (ÜAK), 03.07.1998 tarihinde Muğla Üniversitesi Beden Eğitimi ve Spor Yüksekokulu bünyesinde Rekreasyon Bölümü açılması yönünde Yüksek Eğitim Kurulu Başkanlığı'na görüş bildirmiştir. Yükseköğretim Kurumu, 12.04.2000 tarihinde Beden Eğitimi ve Spor Yüksekokulları (BESYO) bünyesinde Rekreasyon Bölümü'nün açılmasına karar vermiştir. İlk olarak, Orta Doğu Teknik Üniversitesi, Marmara Üniversitesi ve Gazi Üniversitesi'nde Rekreasyon Bölümü açılmıştır (Zorba, 2008: 5354). Böylece rekreasyon, eğitim ve öğretimde kendine yer edinmeye başlamıştır. Zamanla turizm ile ilgili yüksekokulların fakülteleşmesiyle birlikte Rekreasyon bölümleri de Turizm Fakülteleri altında kendine yer bulmaya başlamıştır.

Türkiye'deki akademik yapılanmadan da anlaşılabileceği gibi boş zaman ve rekreasyon kavramları, spor ve turizm ile yakından ilişkilidir. Boş zaman ve rekreasyonun eğitim, peyzaj mimarlığı, sosyoloji, işletme, coğrafya, şehir planlama ve biyoloji (Kızanlıklı, 2014: 54; Ayar ve Koç, 2018: 106; Aydın ve Aksöz, 2019: 622) gibi diğer bilim dallarıyla olan etkileşimi, disiplinlerarası özelliğe sahip olduğunu göstermektedir (Williams, 2006: 92-93). Boş zamanın bu özelliği, alanının gelişimine de katkı sağlamaktadır. Farklı bilim alanlarının boş zamana dair çalışmalar gerçekleştirmesi, zamanla bu alana yönelik ilginin artmasına neden olmuştur. Boş zamana yönelik bu ilginin belirli aralıklarla incelenmesi, bilimsel çalışmaların mevcut durumu, gelişimi ve yönelimleri hakkında bilgi sunabilir (Kozak, 1994). Literatürün düzenli bir şekilde incelenmesi, teorik ve uygulamalı bilgi çeşitliliğinin anlaşılması, konuya dair araştırmaların 
pekiştirilmesi ve çalışılan konu özelinde ilişkilendirmeler yapılabilmesinde önemli katkılar sunabilir (Tranfield vd., 2003 ve Crossan ve Apaydın, 2010). Bu katkının elde edilmesinde bibliyometri, önemli bir yere sahiptir.

\section{Bibliyometri}

Bibliyometri, "biblio" ve "metrics" köklerinden türemiştir. "Biblio" kelimesi Latin ve Grekçe olan ve "kitap" anlamına gelen "bybl(os)" kelimesine eş değer "biblion" kelimesinden gelir. "Metrics" ise Latin ve Grekçe olan "metricus" veya "metrikos" kelimelerinden gelmekte ve "ölçü bilimi" anlamını taşımaktadır (Sengupta, 1992: 76). Bibliyometri, karar vericiler, yöneticiler, araştırmacılar, bilim insanları ve kütüphaneciler tarafından sıklıkla kullanılmaktadır (Prendlebury, 2008: 2'den aktaran; Yetiş ve Çokal, 2018: 41).

"Bibliyometri" ilk kez bir kavram olarak 1969 yılında Pritchard tarafından ortaya konulmuştur. $\mathrm{Bu}$ kavram, "matematik ve istatistiksel yöntemlerin kitaplara ve diğer iletişim araçlarına uygulanması" olarak tanımlanır. Bibliyometri, yazılı iletişim süreci için bir rehber niteliği taşır. Bunun yanında belirli bir bilimsel disiplinin doğasını ve gelişimini de analiz eder (Pritchard, 1969). Bibliyometri, 1970 yılından itibaren iletişim, bilgisayar bilimi, ekonomi, eğitim ve psikoloji gibi çeşitli disiplinlerde yaygın olarak kullanılmaya başlanmış ve zaman içinde sosyoloji, tarih, kütüphane ve bilgi biliminde bir alt disiplin haline gelmiştir (Lee, 2015; Zopiatis vd., 2015; Aydın ve Aksöz, 2019: 617). Fairthorne (1969), bibliyometrinin çerçevesini, kaydedilen söylemin özellikleri ve bunlarla ilişkili davranışların niceliksel işleyişi olarak değerlendirmektedir. Schrader (1981: 151), bibliyometriyi teknik bir bilim olarak ele almakta ve kaydedilmiş söylemlerin sayısal olarak karakterize edilmesi şeklinde tanımlamaktadır. Diodato (1994) ise bibliyometriyi, bilimsel üretkenliğin nicel olarak incelenmesini sağlayan ve akademik araştırmaların analizinde uygulanabilen bir yöntem olarak tanımlamaktadır. Ayrıca bilimsel çalışmalarda yer alan alıntı, yazar, anahtar kelimeler, tartışılan konular, yöntemler gibi parametreler istatistiki yöntemlerle kategorize edilir, betimlenir ve değerlendirilir (Diodato, 1994'ten aktaran Köseoğlu vd., 2016: 180). Bibliyometri, kitap ve dergilerde yer alan araştırmaların kullanımına, tarihsel çerçevede gelişimine, ilgili istatistiklerin toplanmasına ve yorumlanmasına olanak tanır (Raisig, 1962). Roy ve Başak (2013: 2) bibliyometriyi, yazılı belgelerin bilimsel iletişim sürecini değerlendirmek için niceliksel yöntemlerin kullanıldığı bir disiplin olarak tanımlar. Bibliyometrik analizler sayesinde alanyazının gelişimine dair gözlemler ve niceliksel analizler yapılarak o alana ilişkin katkılar sunulabilmektedir (Okubo, 1997). Bilimsel çalışmaların gelişim sürecinin ve özelliklerinin ortaya konulmasında bibliyometri, etken bir rol üstlenmektedir. Bibliyometri, ilgili alanın gelişim sürecini analiz etmek için matematiksel ve istatistiksel yöntemler kullanır. Ayrıca bilimsel çerçevede kimin, neyi, nerede ve nasıl araştırdığı ile ilgili incelemeler yapmaya imkân verir (Sanchez, 2017).

Bibliyometrik çalışmaların önemli bir kısmı, dergilerin bibliyometrik profillerinin belirlenmesine dayanmaktadır. Campbell tarafından 1896 yılında yayımlanan "Theory of the National and International Bibliography" başlıklı çalışmanın içerik açısından ilk bibliyometri çalışması olduğu öne sürülmektedir (Sengupta, 1992). Lawani (1981) ise literatürdeki ilk bibliyometrik araştırmanın Cole ve Eales tarafından 1917'de gerçekleştirilen çalışma olduğunu ileri sürmektedir. İngiliz Patent Ofisi'nde kütüphaneci olan E. Wyndham Hulme tarafından 1923 yılında tarih alanında istatistiki bir analizin yapıldığı belirtilmektedir (Bozkurt ve Çetin, 2016). Goodall, Barry ve Westing (1972), Public Administration Review' de yayımlanan makaleleri çeşitli bibliyometrik özellikler açısından değerlendirmişlerdir. Perry ve Kraemer (1986), aynı derginin 1975-1984 yılları arasında yayımlanan makalelerini kullanılan araştırma yöntemleri açısından incelemişlerdir. Miller ve Serzan (1984), hakemli dergilerin kriterlerine yönelik bir çalışma 
yapmışlardır. Schubert (2002), bibliyometri alanında kaynak olma özelliğine sahip olan ve 1978 yılından itibaren yayınlanan "Scientometrics" dergisinin ilk 50 sayısında yer alan çalışmaları, yazar sayısı ve ortak yazarlık kapsamında ele almıştır. Bir başka çalışmada ise aynı dergide yayımlanan makaleler, yayınların coğrafi dağılımı, yazarların çalıştıkları kurumlar ve ortak yazarlık yönünden değerlendirilmiştir (Dutt vd., 2003). Park (2002), D-Lib Magazine Dergisi'ni, atıf durumu, yazarların yayın sayıları ve çalıştıkları kurum gibi bibliyometrik değerler çerçevesinde incelemiştir (Çiçek ve Kozak, 2012: 737).

Bibliyometrinin 1990'lı yılların sonlarında turizm alanında da kendini gösterdiği bilinmektedir (Evren ve Kozak, 2014: 62). Bibliyometrinin turizm alanındaki çalışmalar için tercih edilmesinde turizmin bir disiplin olarak kabul görmesi, bu konuda yayın yapan akademisyen sayısının artması, bilim insanlarının ve yayın kuruluşlarının turizm literatürüne sağladıkları katkıların incelenmesine duyulan merak ve kişilerin veya kuruluşların araştırma performanslarının değerlendirilmesi ihtiyacının etken olduğu düşünülmektedir (Hall, 2011). Bu doğrultuda turizm üzerine bibliyometrik çalışmaların gerçekleştirilmesinin de hem alana hem de incelenen konulara dair geniş bir bakış açısı yaratabileceği varsayılabilir. Alanyazındaki çalışmaların turizm dergilerinde yayımlanan makalelere (Jogaratnam vd., 2005; Palmer vd., 2005; McKercher vd., 2006; Jamal vd., 2008; Kim vd., 2009; Rogerson ve Rogerson, 2011; Nunkoo vd., 2013; Evren ve Kozak, 2014; Koç ve Boz, 2014; Cheng vd., 2016; Köseoğlu vd., 2016; Okumuş vd., 2018) ve lisansüstü tezlere (Jafari ve Aaser, 1988; Hall, 1991; Meyer-Arendt, 2000; Bao, 2002; Meyer-Arendt ve Justice, 2002; Tayfun vd., 2016; Sünnetçioğlu vd., 2017; Aydın ve Aksöz, 2019) yönelik olduğu görülmektedir.

Çalışmaların dikkate aldığı parametrelerin, makalenin konusu, "yıllara göre dağılımı, araştırma yaklaşımları, sayfa sayıları, yazar unvanları, yazar sayısı, kurum sayısı, atıf sayıları, kaynak sayısı, yayın dili, dergilere göre dağılım, makalelerin kavramsal/ampirik olma açısından durumu, alt alanlar, araştırma alanları, yayın sayısı, yazarlık durumu, anahtar kelime, enstitü dağılımı, derginin alanlarına göre ve yazarların çalıştıkları alana göre dağılımı" gibi değişkenler olduğu görülmektedir (Çiçek ve Kozak, 2012; Özel ve Kozak, 2012; Zencir ve Kozak, 2012; Şakar ve Cerit, 2013; Yeşilyurt ve Yeşilyurt, 2013; Cevizkaya vd., 2014; Sökmen ve Özkanll, 2018 ve Yetiş ve Çokal, 2018). Lisansüstü tezlere yönelik bibliyometri çalışmalarının ise gastronomi, destinasyon, rekreasyon, turist rehberliği, sürdürülebilir turizm, turizm ve turizm coğrafyası (Meyer-Arendt, 2000; Bao vd., 2002; Şahin ve Acun, 2015; Tayfun vd., 2016; Dinç, 2017; Sünnetçioğlu vd., 2017; Ayar ve Koç, 2018; Aydın ve Aksöz, 2019; Demirbulat ve Baytok vd., 2019) gibi alanlarda gerçekleştirildiği görülmektedir. Ancak, literatür incelendiğinde "boş zaman, serbest zaman ve rekreasyon" kavramlarını Türkiye' de lisansüstü tezler kapsamında, alt boyutlar ve ilişkilendirilen kavramlar çerçevesinde inceleyen bir çalışmaya rastlanamamıştır. Belirlenen bu eksiklikten hareketle, bu çalışmanın amacı, Türkiye'de boş zaman ve rekreasyon alanlarına yönelik lisansüstü tezleri bibliyometrik özellikleri çerçevesinde değerlendirmek, boş zaman ve rekreasyon alanlarının Türkiye'deki gelişim sürecini ve genel yapısını ortaya koymaktır. Ayrıca boş zaman ve rekreasyon alanlarındaki alt konuların, ilişkilendirilen kavramların ve değişkenlerin gelecek çalışmalara kaynak oluşturması, araştırmacılara konu ve yöntem tercihlerinde yol gösterici bir rehber niteliği taşıyacak olması, çalışmanın önemli bir katkısı olarak belirtilebilir.

\section{YÖNTEM}

Bu çalışmada, betimsel analiz yöntemi kullanılmıştır. Ayrıca rekreasyon ve boş zaman alanına ilişkin mevcut durumun detaylı bir şekilde tanımlanması için tarama modelinden yararlanılmıştır. Çalışma, Türkiye'de rekreasyon ve boş zaman konusundaki bilimsel gelişmelere 
1şık tutabilmek adına Türkiye'de yayımlanan lisansüstü tezlerin incelenmesini kapsamaktadır. Bilimsel çalışmaların düzenli olarak incelenmesi, mevcut alanın bir resminin çizilmesini sağlar. Böylece alanın gelişimini ve eğilimlerini daha net görmek mümkün olabilmektedir. Bilimsel çerçevede lisansüstü tezlerin, o ülkenin incelenen konuya ilişkin durumunu ve yönelimini detaylıca göstermesi (Kozak, 1994) nedeniyle lisansüstü tezlerin incelenmesine karar verilmiştir.

Çalışmanın verilerinin elde edilmesi amacıyla 24-25.10.2019 tarihlerinde Yükseköğretim Kurulu Ulusal Tez Merkezi veri tabanında tarama yapılmış ve 1980-2019 yılları arasında yayımlanan 683 lisansüstü tez olduğu anlaşılmıştır. Ancak yazarlar tarafından oluşturulan erişim kısıtlılıkları ve Türkiye Belge Sağlama Sistemi (TÜBESS) üzerinden açık olan tezlere erişimin sağlanamaması nedeniyle 1987-2019 yılları arasında yayımlanmış olan 536 teze ulaşılabilmiştir. Tezler, "boş zaman, serbest zaman ve rekreasyon" anahtar kelimeleriyle taranmıştır. Araştırmaya dahil edilen anahtar kelimelerin birden fazla olmasının nedeni, boş zaman ve rekreasyonun bu alanlarla ilişkili olması ve çalışmaya dahil edilen tezlerin başlıklarının bu kavramlar çerçevesinde oluşturulmasıdır. Tezler, "yayımlandığı yıl, tezin türü, anahtar kelime, anabilim dalı, uygulanan araştırma yöntemi, veri analiz tekniği, alt boyut ve ilişkilendirilen kavram" parametreleri kapsamında değerlendirilmiştir. Söz konusu parametreler, rekreasyon ve boş zaman alanının mevcut yapısına dair bilgiler verebilmesi ve gelecek çalışmalara temel oluşturabilmesi nedeniyle seçilmiştir.

Araştırmadan elde edilen veriler, bibliyometrik profil elde edilmesi yönünde analiz edilmiştir. Ayrıca çok sayıdaki nitel verinin hızlı bir şekilde analiz edilmesine ve sentezlenmesine katkı sağlayan ve bulguların görselleştirilmesinde, daha kolay anlaşılmasında etkin ve elverişli bir araç olan kelime bulutundan da yararlanılmıştır (Buzlu, 2015: 79). Geçerliliğin arttırılması amacıyla verilerin bulgulara dönüştürülmesinde yorum katılmamış, bulgular betimsel bir yaklaşımla doğrudan aktarılmıştır. Böylece okuyucuya, çalışmanın ulaştığı sonuçları objektif bir şekilde değerlendirme fırsatı verilmiştir. Le Compte ve Goetz (1982'den aktaran; Özel vd., 2018: 219) bu durumun, çalışmanın iç güvenilirliğini arttırabileceğini belirtmiştir. Analizlerin gerçekleştirilmesi sonrasında elde edilen sonuçlara dair tablolar ve kelime bulutları hazırlanmış, değerlendirmeler yapılmıştır.

\section{BULGULAR}

Rekreasyon ve boş zaman alanına ilişkin 1987-2019 yılları arasında 536 adet tezin yazıldığı ve bu alana ilişkin en fazla tezin 68 adet ile 2019 yılında hazırlandığı tespit edilmiştir. Ayrıca 2018 yılında rekreasyon kavramına ilişkin 64 tezin yazıldığı da görülmektedir. Hazırlanan tezlerin yarısından çoğunun (272 tez) son altı yıla ait olduğu sonucuna ulaşılmıştır (Tablo 1).

Tablo 1. Lisansüstü Tezlerin Yayınlanan Yıllara Göre Dağılımı

\begin{tabular}{cccccccccc}
\hline Yillar & N & Yillar & N & Ylllar & N & Ylllar & N & Ylllar & $\mathbf{N}$ \\
\hline $\mathbf{1 9 8 7}$ & 1 & 1994 & 1 & 2001 & 7 & 2008 & 30 & 2015 & 33 \\
$\mathbf{1 9 8 8}$ & 2 & 1995 & 2 & 2002 & 5 & 2009 & 20 & 2016 & 46 \\
$\mathbf{1 9 8 9}$ & 1 & 1996 & 6 & 2003 & 7 & 2010 & 17 & 2017 & 33 \\
$\mathbf{1 9 9 0}$ & 2 & 1997 & 9 & 2004 & 7 & 2011 & 24 & 2018 & 64 \\
$\mathbf{1 9 9 1}$ & 1 & 1998 & 3 & 2005 & 5 & 2012 & 20 & 2019 & 68 \\
$\mathbf{1 9 9 2}$ & 1 & 1999 & 7 & 2006 & 23 & 2013 & 22 & & \\
$\mathbf{1 9 9 3}$ & 4 & 2000 & 7 & 2007 & 30 & 2014 & 28 & & \\
\hline \multicolumn{7}{c}{ Toplam } \\
\hline
\end{tabular}


Hazırlanan tezler anabilim dalları çerçevesinde incelendiğinde, en çok çalışmanın $(146, \% 26,12)$ beden eğitimi ve spor bilimleri anabilimdalında yapıldığı tespit edilmiştir. Ayrıca rekreasyon (85, $\% 15,86)$, peyzaj mimarlığı $(77, \% 14,37)$, turizm $(29, \% 5,41)$ ve beden eğitimi ve spor yöneticiliği $(23, \% 4,29)$ anabilim dallarında da rekreasyon ve boş zaman üzerine yazılan tezlerin oldukça fazla olduğu görülmektedir. Rekreasyon ve boş zaman üzerine gerçekleştirilen çalışmaların anabilim dallarının çeşitliliği dikkat çekmektedir (Tablo 2).

Tablo 2. Rekreasyon ve Boş Zaman Konulu Tezlerin Anabilim Dalları

\begin{tabular}{lcll}
\hline Anabilim Dalı & N & Anabilim Dalı & N \\
\hline Beden eğitimi ve spor bilimleri & 140 & Aile ekonomisi ve beslenme eğitimi & 1 \\
Rekreasyon & 85 & Aile hekimliği & 1 \\
Peyzaj mimarlı̆̆ı & 77 & Atatürk ilkeleri ve inkılap tarihi & 1 \\
Turizm & 29 & Biyo-sistem mühendisliği & 1 \\
Beden eğitimi ve spor öğretmenliği & 23 & Çalşma ekonomisi ve endüstri ilişkileri & 1 \\
Spor yöneticiliği & 20 & Çevre tasarımı & 1 \\
Coğrafya & 14 & Deniz ulaştırma mühendisliği & 1 \\
İşletme & 12 & Ekonomi & 1 \\
Orman mühendisliği & 11 & Endüstri mühendisliği & 1 \\
Eğitim & 10 & Felsefe & 1 \\
Sosyoloji & 8 & Fizik tedavi ve rehabilitasyon & 1 \\
Şehir ve bölge planlama & 8 & Fizyoterapi ve rehabilitasyon & 1 \\
Spor yönetimi & 7 & Halk eğitimi & 1 \\
Spor bilimleri & 6 & İç mimarlık & 1 \\
Çevre mühendisliği & 5 & İktisat & 1 \\
İletişim & 4 & Jeodezi ve coğrafi bilgi teknolojileri & 1 \\
İlköğretim & 4 & Kentsel sistemler ve ulaştırma yönetimi & 1 \\
Radyon, televizyon ve sinema & 4 & Okul öncesi öğretmenliği & 1 \\
Antrenörlük eğitimi & 3 & Psikoloji & 1 \\
Hareket ve antreman & 3 & Rehberlik ve psikolojik danışmanlık & 1 \\
İç mimarlık ve çevre tasarımı & 3 & Sanat ve tasarım & 1 \\
Mimarlık & 3 & Sosyal yapı sosyal değişme & 1 \\
Özel eğitim & 3 & Spor hekimliği & 1 \\
Sosyal hizmet & 3 & Sporda psiko-sosyal alanlar & 1 \\
Spor bilimleri ve teknolojisi & 3 & Su ürünleri & 1 \\
Tarım ekonomisi & 3 & Su ürünleri avlanma ve işleme teknolojisi & 1 \\
Biyoloji & 2 & Tekstil mühendisliği & 1 \\
Biyo-mühendislik ve bilimleri & 2 & Toprak bilimi ve bitki besleme & 1 \\
Çocuk gelişimi ve eğitimi & 2 & Türk edebiyatı & 1 \\
Endüstri ürünleri ve tasarımı & 2 & Yabancı diller & 1 \\
Ergoterapi & 2 & Yaşam boyu öğrenme ve yetişkin eğitimi & 1 \\
Tarımsal yapılar ve sulama & 2 & Yerleşim arkeolojisi & 1 \\
& & Yönetim bilimleri & 1 \\
\hline Toplam & & 536 & 1 \\
\hline & & & 1 \\
& & &
\end{tabular}

Boş zaman ve rekreasyon üzerine gerçekleştirilen tezlerin büyük bir çoğunluğunun yüksek lisans tezlerinden oluştuğu tespit edilmiştir. Oranlar incelendiğinde, yüksek lisans tezlerinin oranının $\% 81,34$ (436) ve doktora tezlerinin oranının ise \%18,66 (100) olduğu görülmektedir. Tezlerin 
araştırma türleri incelendiğinde ise çalışmaların büyük oranda nicel araştırma türü kategorisinde $(427, \% 79,66)$ olduğu görülmektedir. Bunu sırasıyla nitel araştırma türünde $(99, \% 18,47)$ ve karma yöntemle $(10, \% 1,87)$ yazılan tezler izlemektedir (Tablo 3).

Tablo 3. Tezin Türü ve Tezde Kullanılan Araştırma Türü

\begin{tabular}{lclc}
\hline Tez Türü & $\mathbf{N}$ & Araştırma Türü & $\mathbf{N}$ \\
\hline Yüksek lisans & 436 & Nicel & 427 \\
Doktora & 100 & Nitel & 99 \\
& & Karma & 10 \\
\hline Toplam & $\mathbf{5 3 6}$ & Toplam & $\mathbf{5 3 6}$ \\
\hline
\end{tabular}

Tablo 4. Lisansüstü Tezlerde Yer Alan Anahtar Kelimeler

\begin{tabular}{|c|c|c|c|}
\hline Anahtar Kelimeler & $\mathbf{N}$ & Anahtar Kelimeler & $\mathbf{N}$ \\
\hline Rekreasyon & 230 & Hizmet kalitesi & 9 \\
\hline Boş zaman & 83 & Sağlik & 9 \\
\hline Serbest zaman & 78 & Tasarım & 9 \\
\hline Turizm & 62 & Tatmin & 9 \\
\hline Spor & 48 & Egzersiz & 8 \\
\hline Boş zaman etkinlikleri ve faaliyetleri & 45 & Kiy1 & 8 \\
\hline Üniversite ve öğrenciler & 38 & Kültür & 8 \\
\hline Parklar & 28 & Mutluluk & 8 \\
\hline Tutum & 22 & Pazarlama & 8 \\
\hline Motivasyon & 21 & Performans & 8 \\
\hline Peyzaj & 19 & Rekreasyon alanları & 8 \\
\hline Fiziksel aktivite & 17 & Rekreasyon potansiyeli & 8 \\
\hline $\begin{array}{l}\text { Beden eğitimi ve spor, öğretmenliği, } \\
\text { öğretmenler }\end{array}$ & 16 & Zaman & 8 \\
\hline Boş zaman değerlendirme & 14 & Açık alan/hava rekreasyonu & 7 \\
\hline Doğa, çevre koruma ve kullanımı & 14 & Boş zaman tatmini & 7 \\
\hline Doyum & 13 & Davranış & 7 \\
\hline Gençlik ve gençlik merkezleri & 13 & Deneyim & 7 \\
\hline $\begin{array}{l}\text { Rekreasyon faaliyetlerine katılım ve } \\
\text { etkileyen faktörler }\end{array}$ & 13 & Eğitim & 7 \\
\hline Engellilik & 12 & Hizmet & 7 \\
\hline Lider/lik & 12 & Öznel iyi olma & 7 \\
\hline Mekan & 11 & Rekreasyon alanı & 7 \\
\hline Yaşam doyumu & 11 & Rekreasyon planlama & 7 \\
\hline Yaşam kalitesi & 11 & Rekreasyon yönetimi & 7 \\
\hline Sportif rekreasyon ve aktiviteler & 10 & Serbest zaman engelleri & 7 \\
\hline Oyunlar & 10 & Serbest zaman tatmini & 7 \\
\hline Planlama & 10 & Diğer & 890 \\
\hline Çevre & 9 & & \\
\hline \multicolumn{2}{|l|}{ Toplam } & \multicolumn{2}{|l|}{1952} \\
\hline
\end{tabular}


İncelenen tezlerin anahtar kelimeleri değerlendirildiğinde rekreasyon anahtar kelimesinin (230, $\% 11,78)$ başı çektiği görülmektedir. Bunu sırasıyla boş zaman $(83, \% 4,25)$, serbest zaman $(78$, $\% 4,00)$, turizm $(62, \% 3,18)$, spor $(48, \% 2,46)$ ve boş zaman etkinlikleri ve faaliyetleri $(45, \% 2,31)$ anahtar kelimelerinin izlediği görülmektedir. Tezlerde birbirinden farklı oldukça fazla sayıda anahtar kelimenin kullanıldığı tespit edilmiştir. Az tekrarlanan anahtar kelimeler, "diğer" başlığı altında verilmiştir (Tablo 4).

Tezlerin veri analiz teknikleri incelendiğinde en fazla yararlanılan tekniklerin sırasıyla yüzde $(352, \% 19,75)$, siklık $(251, \% 14,09)$, varyans analizi $(172, \% 9,65)$, t-testi $(160, \% 8,98)$, ki-kare analizi $(104, \% 5,84)$ ve korelasyon analizi $(102, \% 5,72)$ olduğu tespit edilmiştir. Bazı analizlerin bir kez kullanıldığı sonucuna ulaşılmıştır. Bu analizlere "diğer analizler" başlığı altında yer verilmiştir. Çalışmalarda çok sayıda analizden yararlanıldığı görülmektedir (Tablo 5).

Tablo 5. Tezlerde Kullanılan Veri Değerlendirme Teknikleri

\begin{tabular}{|c|c|c|c|}
\hline Veri Analiz Teknikleri & $\mathbf{N}$ & Veri Analiz Teknikleri & $\mathbf{N}$ \\
\hline Yüzde & 352 & $\begin{array}{l}\text { Sulama sistemleri, su değerleri ve deniz suyu } \\
\text { analizleri }\end{array}$ & 9 \\
\hline Siklık & 251 & Alan, bitki ve çevresel analizler & 9 \\
\hline Varyans analizi & 172 & Yapısal eşitlik & 7 \\
\hline T-testi & 160 & Sportif/Açık hava rekreasyon değeri yöntemi & 7 \\
\hline Ki-kare & 104 & Sosyolojik ve toplumbilimsel analiz & 7 \\
\hline Korelasyon analizi & 102 & $\begin{array}{l}\text { Ekolojik planlama ve taşıma kapasitesi } \\
\text { yöntemleri }\end{array}$ & 7 \\
\hline Ortalama & 73 & Seyahat maliyeti yöntemi & 6 \\
\hline Mann-Whitney U & 58 & $\begin{array}{l}\text { Turizm tesisleri durum ve değerlendirme } \\
\text { analizleri }\end{array}$ & 4 \\
\hline Kruskal Wallis & 54 & Peyzaj analizi & 4 \\
\hline İçerik analizi & 48 & Pet analizi & 4 \\
\hline Regresyon & 43 & Kümeleme analizi & 4 \\
\hline $\begin{array}{l}\text { Coğrafi bilgi sistemleri } \\
\text { analizleri }\end{array}$ & 43 & Koşullu değer belirleme yöntemi & 4 \\
\hline Çoklu karşılaştırma testleri & 31 & Fiziksel-kimyasal ve toprak analizleri & 4 \\
\hline Çapraz tablolama & 30 & Önem derecesi analizi & 3 \\
\hline Rekreasyonel & 25 & Doğal ve kültürel faktörler analizi & 3 \\
\hline \multicolumn{4}{|l|}{ kullanılabilirlik yöntemi } \\
\hline Betimsel analiz & 22 & Kelime bulutu, atıf analizi, sosyal ağ analizi & 3 \\
\hline Doküman analizi & 20 & Tarihsel ve etnografik analiz & 3 \\
\hline Manova & 15 & Tümevarım analizi & 2 \\
\hline Swot, A'wot & 13 & Trix indeksi & 2 \\
\hline Görsel kalite analizi & 13 & Ölçüt karneler yöntemi & 2 \\
\hline Wilcoxon analizi & 9 & Mekânsal analiz & 2 \\
\hline Durum analizi & 9 & Diğer & 39 \\
\hline \multicolumn{2}{|l|}{ Toplam } & \multicolumn{2}{|l|}{1782} \\
\hline
\end{tabular}

Alt boyutlar değerlendirildiğinde en çok odaklanılan konunun rekreasyon faaliyetleri ve etkinlikler $(127, \% 12,43)$ olduğu görülmektedir. Bu boyutu, rekreasyon katılım ve düzeyleri (53, $\% 5,19)$, rekreasyon değerlendirme ve ilgilenimi $(51, \% 4,99)$, rekreasyon potansiyeli ve olanakları 
$(46, \% 4,50)$, rekreasyon planlama $(45, \% 4,40)$ ve rekreasyon ve katılımı etkileyen/destekleyen faktörler $(40, \% 3,91)$ boyutları izlemektedir. Çalışmalarda çok sayıda alt boyuta yer verildiği ve buna ilişkin değerlendirmelerin yapıldığ 1 tespit edilmiştir. Bazı boyutlar bir kez tekrarlandığından bunlara "diğer alt boyutlar" başlığı altında yer verilmiştir (Tablo 6). Alt boyutların yayımlanan tezlerdeki dağılımının şekilsel gösteriminde ise kelime bulutundan yararlanılmıştır (Şekil 1).

Tablo 6. Lisansüstü Tezlerde Yer Alan Rekreasyon ve Boş Zaman Alanına İlişkin Alt Boyutlar

\begin{tabular}{|c|c|c|c|}
\hline Alt Boyutlar & $\mathbf{N}$ & Alt Boyutlar & $\mathbf{N}$ \\
\hline Rekreasyon faaliyetleri ve etkinlikler & 127 & Rekreasyon talebi & 12 \\
\hline Rekreasyon katılım ve düzeyleri & 53 & $\begin{array}{l}\text { Serbest zaman doyumu ve } \\
\text { faktörleri }\end{array}$ & 12 \\
\hline Rekreasyon değerlendirme ve ilgilenimi & 51 & Kentsel rekreasyon & 11 \\
\hline Rekreasyon potansiyeli ve olanakları & 46 & Terapötik rekreasyon & 9 \\
\hline Rekreasyon planlama & 45 & Rekreasyon algisi & 8 \\
\hline $\begin{array}{l}\text { Rekreasyon ve katılımı etkileyen/destekleyen } \\
\text { faktörler }\end{array}$ & 40 & $\begin{array}{l}\text { Rekreasyon kaynakları ve } \\
\text { değerleri }\end{array}$ & 8 \\
\hline $\begin{array}{l}\text { Rekreasyon katılım engelleri ve baş etme } \\
\text { stratejileri }\end{array}$ & 34 & Kiyı rekreasyonu & 8 \\
\hline Sportif rekreasyon program ve faaliyetleri & 32 & Ciddi/kayıtsız boş zaman & 8 \\
\hline $\begin{array}{l}\text { Rekreasyon beklentileri, tercihi ve etkileyen } \\
\text { faktörler }\end{array}$ & 31 & Rekreasyonel egzersizler & 8 \\
\hline Rekreasyon ve değerlendirme alışkanlıkları & 29 & Suya dayalı rekreasyon & 7 \\
\hline Rekreasyon alanları & 28 & Kirsal rekreasyon & 7 \\
\hline $\begin{array}{l}\text { Boş zaman değerlendirme eğilimleri ve } \\
\text { özellikleri }\end{array}$ & 27 & İş yeri rekreasyonu & 7 \\
\hline Rekreasyon kullanımı, amaçları ve şekli & 26 & Rekreasyonel liderlik & 6 \\
\hline Rekreasyon yararları & 22 & Boş zamanda sıkılma & 5 \\
\hline Rekreasyon bölümü ve eğitimi & 22 & Kampüs rekreasyonu & 5 \\
\hline Rekreasyon programla(ma)ri/hizmetleri & 22 & Boş zaman sosyolojisi & 5 \\
\hline Serbest zaman tatmini & 21 & Ticari rekreasyon & 4 \\
\hline Rekreasyon tür ve çeşitleri & 21 & $\begin{array}{l}\text { Boş zamanda algilanan } \\
\text { özgürlük }\end{array}$ & 4 \\
\hline Rekreasyon sınıflandırması & 20 & Boş zaman deneyimi & 4 \\
\hline Rekreasyonel mekanlar, tesisler ve faydalanma & 20 & Rekreasyon fonksiyonları & 4 \\
\hline Açık alan/hava rekreasyonu & 19 & $\begin{array}{l}\text { Rekreasyonel taşıma } \\
\text { kapasitesi }\end{array}$ & 4 \\
\hline Orman/içi rekreasyon & 17 & Rekreasyon ilişkileri & 4 \\
\hline Rekreasyonel motivasyon & 15 & Macera, doğa rekreasyonu & 4 \\
\hline Rekreasyon ve faaliyetlerinin etkileri & 15 & Boş zaman önemi & 4 \\
\hline Boş zaman tutumu & 14 & Boş zaman tüketimi & 3 \\
\hline Rekreasyon ihtiyacı & 13 & Boş zaman pazarlaması & 3 \\
\hline Rekreasyon davranışları & 13 & Ekolojik temelli rekreasyon & 3 \\
\hline Rekreasyon yönetimi & 12 & Diğer & 20 \\
\hline Toplam & & 1022 & \\
\hline
\end{tabular}




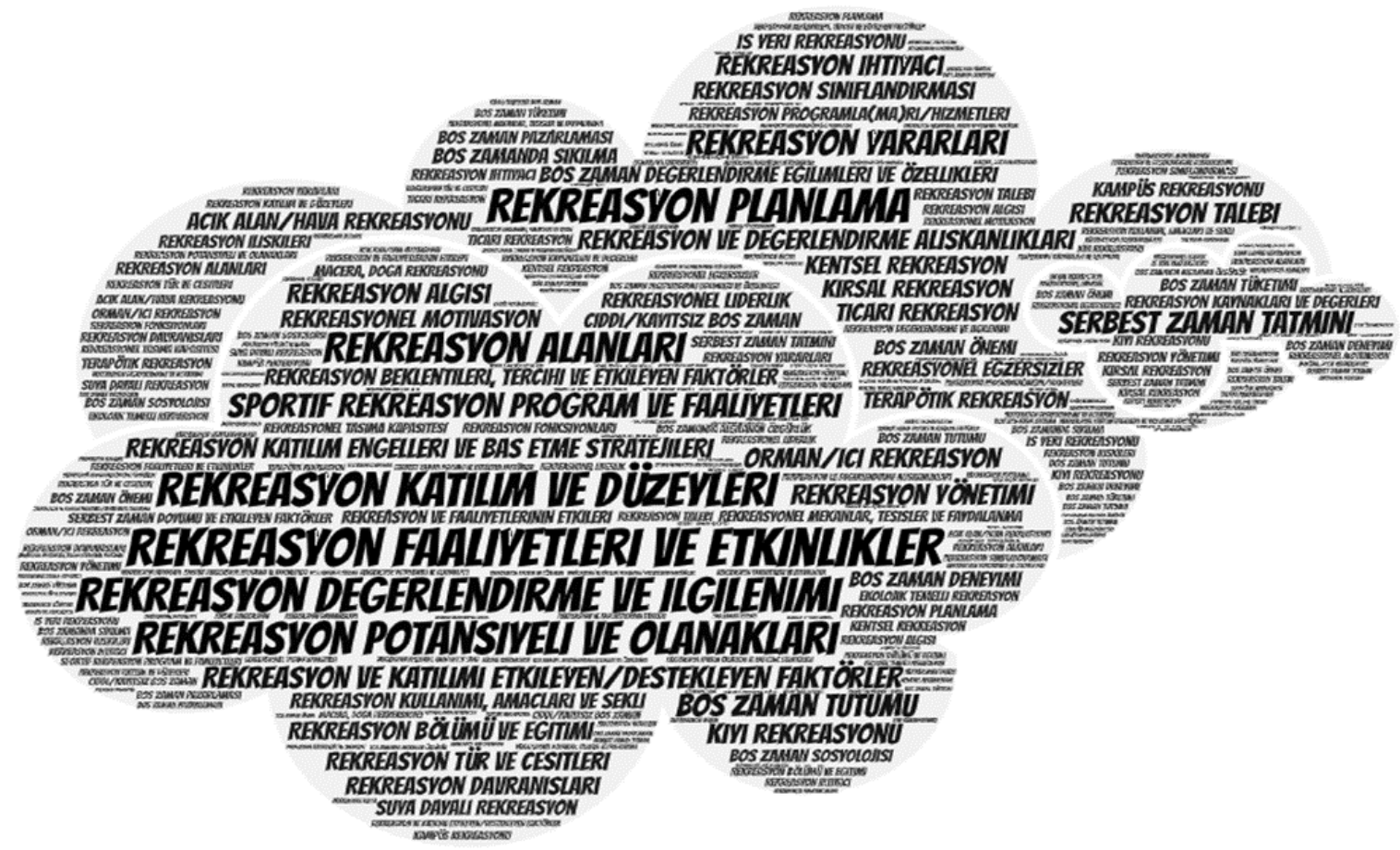

Şekil 1. Lisansüstü Tezlerde Yer Alan Rekreasyon ve Boş Zaman Alanına İlişkin Alt Boyutların Kelime Bulutu Gösterimi

Tablo 7. Lisansüstü Tezlerde Rekreasyon ve Boş Zaman Alanıyla İlişkilendirilen Kavramlar

\begin{tabular}{|c|c|c|c|c|c|}
\hline İlişkilendirilen Kavramlar & $\mathbf{N}$ & İlişkilendirilen Kavramlar & $\mathbf{N}$ & İlişkilendirilen Kavramlar & $\mathbf{N}$ \\
\hline Turizm & 70 & Gelişimsel yetersizlik/Engellilik & 7 & Taşıma kapasitesi & 3 \\
\hline Spor & 33 & Gelişim özellikleri/Ergenlik & 7 & Sosyoloji & 3 \\
\hline Peyzaj & 32 & Örgütsel kavramlar & 7 & Sosyal kurum & 3 \\
\hline Kalite & 31 & Yerel yönetim & 6 & Sikilma & 3 \\
\hline Gençlik & 26 & Tasarım & 6 & Saldırganlık ve öfke & 3 \\
\hline $\begin{array}{l}\text { Doğal, kültürel ve tarihi } \\
\text { mekanlar }\end{array}$ & 21 & Sosyalleşme & 6 & $\begin{array}{l}\text { Risk alma davranışları ve } \\
\text { davranış }\end{array}$ & 3 \\
\hline Doyum & 19 & $\begin{array}{l}\text { Sosyal ağ siteleri ve sosyal } \\
\text { medya }\end{array}$ & 6 & Özgürlük & 3 \\
\hline Motivasyon & 18 & Sağllk & 6 & Okul öncesi & 3 \\
\hline Kent/leşme & 18 & Öznel iyi oluş & 6 & Beceri & 3 \\
\hline Egzersiz & 18 & Öğrenme & 6 & İlgilenim & 3 \\
\hline Tatmin ve memnuniyet & 18 & Kişilik & 6 & İklim ve sosyo-kültürel iklim & 3 \\
\hline Eğitim & 17 & Ekoloji & 6 & Heyecan arayışı & 3 \\
\hline Engellilik & 15 & Akademik başarı & 6 & Destinasyon & 3 \\
\hline Çevre & 15 & Benlik ve kimlik & 6 & Kültürel miras & 2 \\
\hline Yönetim & 14 & Alg1 ve Güdü/lenme & 6 & Zihinsel iş yükü & 2 \\
\hline Kültür/leşme & 14 & Sanat & 5 & Umutsuzluk & 2 \\
\hline $\begin{array}{l}\text { Çalışma, çalışma etiği ve } \\
\text { performansı }\end{array}$ & 13 & Animasyon & 5 & Termal konfor alanı & 2 \\
\hline Tutum & 12 & Toplum/sallaşma & 5 & Takım çalışması & 2 \\
\hline Ekonomik değer & 12 & $\begin{array}{l}\text { Tüketim, tüketim kültürü ve } \\
\text { mekanları }\end{array}$ & 5 & Okuma alışkanlığı ve pratiği & 2 \\
\hline Liderlik & 10 & Yabancılaşma & 4 & Müfredat & 2 \\
\hline Sürdürülebilirlik & 9 & Tükenmişlik & 4 & Marka/laşma & 2 \\
\hline Planlama & 9 & Pazarlama & 4 & Kariyer & 2 \\
\hline Oyunlar & 9 & Parklar & 4 & Kararlılık ve karar verme & 2 \\
\hline Orman & 9 & $\begin{array}{l}\text { Bitkiler, flora, } \\
\text { mikroorganizmalar }\end{array}$ & 4 & Emek ve istihdam & 2 \\
\hline Medya ve iletişim & 9 & Sosyal-Ruhsal uyum & 4 & Davranışsal niyet & 2 \\
\hline Mutluluk & 8 & Zeka ve duygusal zeka & 3 & Atılganlık & 2 \\
\hline Stres ve depresyon & 8 & Yaşam tarzı & 3 & Diğer & 35 \\
\hline Yaşl1lık & 7 & Yalnızlık & 3 & & \\
\hline Toplam & & & & 741 & \\
\hline
\end{tabular}


Rekreasyon alanının ilişkilendirildiği kavramlar incelendiğinde en çok ilişkilendirilen kavramın turizm $(70, \% 9,45)$ olduğu sonucuna ulaşılmıştır. Turizmi sırasıyla spor $(33, \% 4,45)$, peyzaj $(32$, $\% 4,32)$, kalite $(31, \% 4,32)$, gençlik $(26, \% 3,51)$ ve doğal, kültürel ve tarihi mekanlar $(21, \% 2,83)$ kavramlarının takip ettiği görülmektedir. Rekreasyon alanının birçok kavramla ilişkilendirildiği tespit edilmiştir. Bazı kavramların bir kez tekrarlanması sebebiyle bu kavramlara "diğer kavramlar" başlığı altında yer verilmiştir (Tablo 7). Rekreasyon alanının ilişkilendirildiği kavramların şekilsel gösteriminde ise kelime bulutundan yararlanılmıştır (Şekil 2).

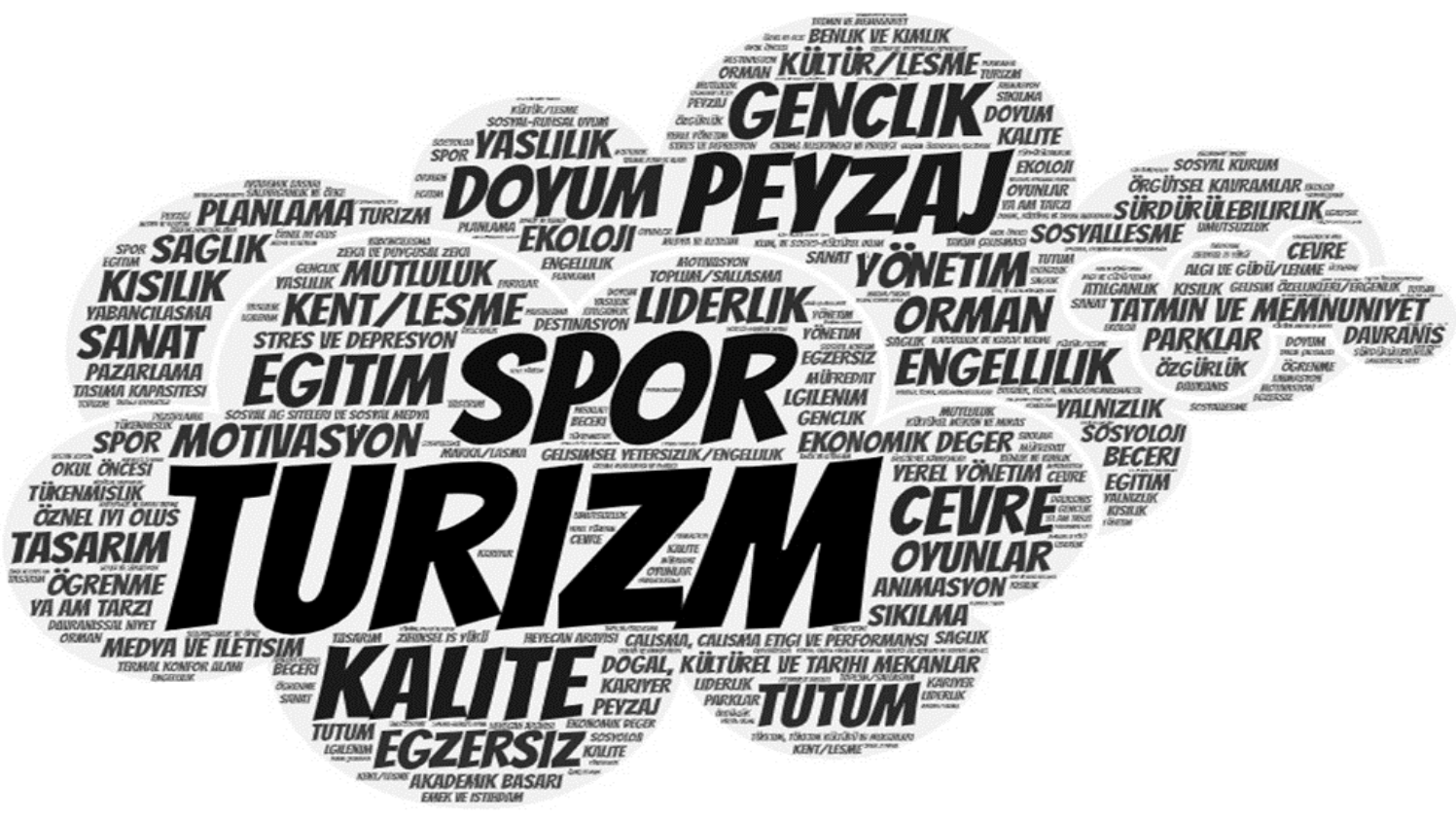

Şekil 2. Lisansüstü Tezlerde Rekreasyon ve Boş Zaman Alanıyla İlişkilendirilen Kavramların Kelime Bulutu Gösterimi

\section{TARTIŞMA ve SONUÇ}

Bu çalışmada Türkiye'de "boş zaman, serbest zaman ve rekreasyon" alanlarına yönelik hazırlanan lisansüstü tezlerin bibliyometrik özellikler çerçevesinde değerlendirilmesi amaçlanmıştır. Bu çerçevede Yükseköğretim Kurulu Ulusal Tez Merkezi (YÖKTEZ) veri tabanından ulaşılan 536 tez incelenmiştir. Bu incelemede lisansüstü tezlerin "yayınlandığı yıl, tezin türü, anahtar kelimeler, anabilim dalı, uygulanan araştırma yöntemi, veri analiz tekniği, alt boyutlar ve ilişkilendirilen kavramlar" faktörleri dikkate alınarak incelenen alanın profili ortaya çıkarılmıştır.

Çalışmada 1987-2019 yılları arasında gerçekleştirilen tezler yer almıştır. Rekreasyon ve boş zaman üzerine yazılan tezlerin 2019 ve 2018 yıllarında en çok sayıya ulaştığı görülmektedir. Ayrıca hazırlanan tezlerin yarısından çoğunun son altı yılda yapıldığı tespit edilmiştir. Bu durumun nedeni, rekreasyon ve boş zaman alanına ilginin son yıllarda artması olabilir. Buna ek olarak bu durum, alanda hem akademik hem de sektörel gelişimlerin bir yansıması olabilir.

Lisansüstü tezlerin çoğunluğunu yüksek lisans tezlerinin oluşturduğu görülmektedir (Çetinkaya, 2011; Kızanlıklı, 2014 ve Ayar ve Koç, 2018). Bu durumun nedeni doktora programlarının görece daha az sayıda olması ve yüksek lisans programlarından daha sonra 
açılmaya başlanması olabilir. Ayrıca hem yüksek lisans hem de doktora programlarında boş zaman ve rekreasyon alanına ilişkin çalışmalara yer verilmesinin bu alanın akademik ilerlemesine katkı sağladığı ifade edilebilir. Lisansüstü tezlerin hazırlandığı anabilim dalları incelendiğinde liderliğin, beden eğitimi ve spor bilimleri alanlarında olduğu tespit edilmiştir. Bu durumun, üniversitelerin beden eğitimi ve spor yüksekokulları/spor bilimleri fakülteleri altında rekreasyon eğitiminin verilmesiyle yakından ilişkili olduğu söylenebilir. Kızanlıklı'nın (2014) rekreasyon alanında yaptığı çalışmasından farklı olarak bu çalışmada, rekreasyon ve turizm anabilim dallarında hazırlanan lisansüstü tezlerin daha üst sıralarda olduğu görülmektedir. Son yıllarda hazırlanan tezlerin yarısından fazlasının 2014 yılı itibariyle yazıldığ çalışmada tespit edilmiştir. Türkiye'de rekreasyon bölümleri, 2000 yılında açılmaya başlanmıştır. Rekreasyonun yeni bir bölüm olarak gelişmesi ve yaygınlaşması ise zaman almıştır. 1980'lerde rekreasyon araştırmaları, toplumun ekonomik çeşitlilik ve gelişim ihtiyacına bağlı olarak turizmi benimsemiştir. 2009-2010 Eğitim-öğretim yılı ile Turizm Fakülteleri çatısı altında "Rekreasyon Yönetimi" bölümleri açılmaya başlamıştır (Çetinkaya, 2011). Turizm Fakültelerinde Rekreasyon Yönetimi Programı'nın açılması ile boş zaman ve rekreasyon konuları üzerinde yazılan tezlerde artış olduğu söylenebilir. Dolayısıyla turizm ve rekreasyon anabilim dallarındaki sıralama değişikliği, olağan bir durumdur. Turizm ve rekreasyon anabilim dallarında rekreasyon bölümlerinin açılmasıyla birlikte rekreasyon ve boş zaman konulu tezlerin son yıllarda atılım gösterdiği görülmektedir. Ayrıca insanların boş zaman değerlendirmesine daha fazla önem göstermesi, sektörü hareketlendirdiği gibi akademiyi de çalışmalar üretmeye itmiştir.

Çalışmada tezlerin araştırma türleri incelendiğinde nicel araştırma yöntemine eğilimin daha fazla olduğu sonucuna ulaşılmıştır. Bu durumun pozitivist bakış açısıyla ilişkili olduğunu söylemek olağan karşılanabilir. Son yıllarda pozitivist bakış açısından ziyade yorumlayıcı ve eleştirel paradigmalar çerçevesinde yönelimlerin olduğunu belirtmek mümkündür. Ayrıca sosyal bilimler enstitüsü sayısında ve sosyal bilimler dergilerinin sayısında artışlar olduğu belirtilmektedir (Seymen vd., 2009). Nitel ve karma araştırma yöntemlerinden yararlanılan araştırmalarda artış olduğu görülürken ilerlemenin bu yönde devam edeceği varsayılabilir.

İncelenen tezlerin anahtar kelimeleri dikkate alındığında rekreasyon anahtar kelimesinin ön plana çıktığı görülmektedir. Çalışmada Ayar ve Koç (2018) ve Çetinkaya'nın (2011) rekreasyon alanına ilişkin gerçekleştirdikleri çalışmalarda incelenen anahtar kelimelerin tekrarlanma sayısı, "rekreasyon, boş zaman ve serbest zaman" anahtar kelimeleri çerçevesinde benzerlik göstermektedir. Ancak "turizm ve spor" anahtar kelimelerine Ayar ve Koç (2018) ve Çetinkaya'nın (2011) çalışmalarında rastlanılmamış olması, araştırmacıların bu kavramları ana konular içinde sınıflandırmasından kaynaklanmaktadır. Ayrıca en fazla tekrarlanma sayısının rekreasyon, boş zaman ve serbest zaman anahtar kelimelerinde görülmesinin, çalışılan alana ilişkin bir sonuç olduğu söylenebilir. Buna ek olarak "turizm, spor ve boş zaman etkinlikleri/faaliyetleri" anahtar kelimelerinin de dikkate değer bir sayıda tekrarlandığı görülmüştür. Turizm ve beden eğitimi ve spor anabilim dallarında boş zaman ve rekreasyon alanına ilişkin çalışmaların oldukça fazla olması, bu durumun bir göstergesi olabilir. Ayrıca boş zaman ve boş zaman etkinlikleri anahtar kelimesinin Ayar ve Koç'un (2018) çalışmasında yer almadığ görülmektedir. Bunun rekreasyon, boş zaman ve serbest zaman etkinlikleri ve faaliyetleri anahtar kelimelerinin birleştirilmesinden kaynaklandığını söylemek mümkündür. Çalışmalarda çok sayıda anahtar kelimenin yer aldığı görülmektedir. Bu durum, boş zaman ve rekreasyon alanının farklı alanlarda da çalışıldığının bir göstergesidir. Ayrıca rekreasyon, boş zaman ve serbest zaman anahtar kelimelerinin kullanım yoğunluğunun bu kavramların birbirleriyle ilişkili olmasından kaynaklandığı ifade edilebilir.

Lisansüstü tezlerin veri değerlendirme teknikleri incelendiğinde en fazla yararlanılan tekniklerin sırasıyla yüzde, sıklık, varyans analizi, t-testi, ki-kare analizi ve korelasyon analizi olduğu tespit 
edilmiştir. Araştırmacıların çalışmalarında yorumlayıcı analizlerden yararlandığı görülmektedir. Çalışmalarda incelenen konular üzerinde ilişkisel ve farksal çerçevede irdelemeler gerçekleştirildiğini söylemek mümkündür. Araştırmacıların çalışmalarında çoğunlukla nicel araştırma yöntemlerinden yararlandığı da görülmektedir. İlişkisel ve farksal analizlere olan bu eğilimin olası bir sonuç olduğunu söylemek mümkündür.

Rekreasyon ve boş zaman alt boyutları incelendiğinde çalışmalarda en sık karşılaşılan alt boyutların rekreasyon ve boş zaman faaliyetleri ve etkinlikleri olduğu sonucuna ulaşılmıştır. Ayrıca rekreasyon ve boş zaman katılımı ve düzeyleri, rekreasyon ve boş zaman değerlendirme ve ilgilenimi, rekreasyon ve boş zaman potansiyeli ve olanakları, rekreasyon ve boş zaman planlama ve rekreasyon ve boş zamanı etkileyen/destekleyen faktörlerin de çalışmalarda oldukça fazla yer aldığ tespit edilmiştir. Çalışmada yer alan boş zaman ve rekreasyon alt boyutlarıyla Ayar ve Koç (2018) ve Çetinkaya'nın (2011) çalışmalarında oluşturulan alt boyut sınıflandırması benzerlik gösterse de farklılıkların da olduğu görülmektedir. Bu farklılıkların araştırmacıların sınıflandırmalarından ve çalışmalarını gerçekleştirdikleri yıllardan kaynaklandığı düşünülebilir. Çalışmaların genel çerçevede alana ilişkin faaliyetlerin ve etkinliklerin kapsamı üzerinde durduğunu belirtmek mümkündür. Lisansüstü tezlerin rekreasyon ve boş zamanın sosyal konuları üzerinde durduğu belirtilebilir. Bu durumun Endüstri Devrimiyle birlikte başlayan sosyo-kültürel değişimin bir ürünü olduğu varsayılabilir. Araştırmacıların ve sektör temsilcilerinin zamana ayak uydurması, olağan bir tepkidir. Tezlerin teknik konular üzerinde de durduğu görülmektedir. Rekreasyon alanının planlanması ve potansiyellerinin belirlenmesi, alana ilişkin değişen ihtiyaçların karşılanabilmesi kapsamında önem arz eder. Dolayısıyla teknik konular üzerinde bir eğilimin oluşması, olağan karşılanabilir. İnsanların boş zamanlarında rekreasyonel faaliyetlerde bulunması, sektörün ilerlemesini olumlu etkileyecektir. Rekreasyon ve boş zaman katılımını etkileyen unsurlar üzerinde durulmasının sektörle akademinin etkileşim içinde olmasından kaynaklandığı söylenebilir. Ayrıca diğer alt boyutlara bakıldığında da hem sosyal hem de teknik konuların farklı bakış açılarıyla ele alındığı gözlemlenebilmektedir.

Çalışmada rekreasyon ve boş zaman alanının daha çok turizm, spor, peyzaj, kalite, gençlik ve doğal, kültürel ve tarihi mekanlar kavramlarıyla ilişkilendirildiği sonucuna ulaşılmıştır. Turizmin rekreasyonun bir alt elemanı olarak görülmesi, en çok ilişkilendirilen kavram olmasına zemin hazırlamış olabilir. Turizm bölümünün altında rekreasyon bölümünün açılması, bunun bir sonucu olabilir. Turizmin içinde barındırdığı özelliklerin rekreasyon ve boş zaman alanında çalışanların dikkatini çektiği söylenebilir. Turizmin ticari bir rekreasyon olması ve turizm faaliyeti olarak belirtilen etkinliklerin (rafting, yamaç paraşütü, mağara turizmi vs.) birer rekreasyon faaliyeti olması, turizmin rekreasyon ve boş zaman alanıla ilişkilendirilen bir kavram olarak öne çıkmasının ana nedeni olarak belirtilebilir. Ayrıca turizmin, rekreasyon ve boş zaman ile içiçe olduğu ve bir etkileşim içerisinde olduğu görülmektedir. Bu durumun turizmin interdisipliner özelliğine de koşut olarak rekreasyon ve boş zaman alanında gerçekleştirilen çalışmaların turizmin bir bilim dalı olma yolundaki gelişimine katkı sunabileceği ifade edilebilir. En çok ilişkilendirilen bir diğer kavramın spor olmasının, rekreasyon bölümünün spor bilimlerinin altında yer almasından ve bazı rekreasyonel faaliyetler ile spor etkinliklerinin birbiriyle olan etkileşimlerinden kaynaklandığı belirtilebilir.

Rekreasyonel alanların kullanımı, potansiyelinin belirlenmesi, oluşturulması ve değerlendirilmesi, rekreasyonel ihtiyaçların karşılanması bağlamında önemli bir yere sahiptir. Doğanın tahrip edilmesi, kentleşme, stres, iş koşulları gibi etkenlerin peyzaj düzenlemeleri ve rekreasyonel olanakların yeniden dizayn edilmesi, rekreasyonel alanlara ihtiyaç oluşturmuş olabilir. Ayrıca boş zaman ve rekreasyon alanında yapılan çalışmaların hizmet kalitesi ve algılanan kalite üzerinde durması, rekreasyonel faaliyetler sunan işletmelerin yaygınlaşmasıyla açıklanabilir. Stres ve kötü iş koşullarının insanların boş zamanlarını değerlendirirken mutlu 
olmalarını olumsuz etkilediği söylenebilir. Bu durum insanların yaşam kalitelerini etkileyecektir. Dolayısıyla boş zaman ve rekreasyon alanında çalışanların yaşam kalitesi üzerinde çalışmalar yapması olağan görülebilir.

Rekreasyon alanının farklı birçok kavramla ilişkilendirildiği, disiplinler arası bir özellik taşıdığı tespit edilmiştir. Bu alanın birçok farklı alanla etkileşim içinde olması nedeniyle alana ilişkin verilen eğitimin farklı bölümler altında verilmesi rekreasyon ve boş zaman alanına farklı bakış açıları getirebilir. Ayrıca farklı disiplinlerin birlikte rekreasyon ve boş zaman alanına ilişkin çalışmalar gerçekleştirmesi, alanın disiplinel anlamda ilerlemesine katkı sunacaktır. Rekreasyon ve boş zaman alanına eğitim bilimleri çatısı altında yer verilmesi, hem nitelikli sektör çalışanlarının yetiştirilmesine hem de alanyazının çeşitlenmesine imkan tanıyacaktır. Rekreasyon ve boş zamana ilişkin bibliyometrik çalışmalarda üniversitelerin öğrenci sayıları, öğretim üyesi sayıları ve unvanları dikkate alınarak çalışmalar yürütülebilir. Yayınlanmış tezler veya makaleler kuramsal çerçevede incelenerek alanın kuramsal profili ve eğilimleri ortaya çıkarılabilir. Kısıtlılıklardan kaynaklı ulaşılamayan tezlere ulaşılarak çalışma genişletilebilir. Yurt dışındaki çalışmalarla karşılaştırmalar yapılarak Türkiye'nin rekreasyon ve boş zaman alanındaki mevcut durumu ortaya konabilir. Lisansüstü tezlerin anabilim dalları, veri analiz teknikleri, alt boyutları ve ilişkilendirilen kavramlar gibi değişkenlerinin yıllar ile karşılaştırılması sağlanabilir. Böylece rekreasyon ve boş zaman alanının dönemsel çerçevede incelenmesi sağlanabilir. Ayrıca ülkenin ekonomik, politik, sosyo-kültürel parametreleriyle ilişkilendirmeler gerçekleştirilebilir. Rekreasyonel faaliyetlerde bulunan yeni ve farklı işletmelerin kurulması ile alanın ilerlemesine katkı sağlanabilir.

\section{KAYNAKÇA}

Al, U. ve Coştur, R. (2007). Türk Psikoloji Dergisi'nin Bibliyometrik Profili, Türk Kütüphaneciliği, 21(2): 142-163.

Ayar, H. ve Koç, M. C. (2018). 1980-2018 Yılları Arası Türkiye'de Rekreasyon Alanında Yapılan Lisansüstü Tezlerin İncelenmesi, Sportif Bakış: Spor ve Eğitim Bilimleri Dergisi, 5(1): 96-107.

Aydın, B. ve Aksöz, O. E. (2019). Destinasyon Alanında Yayınlanmış Lisansüstü Tezlerin Bibliyometrik Profili, Journal of Tourism and Gastronomy Studies, 7(1): 615-636.

Bao, J. (2002). Tourism Geography as The Subject of Doctoral Dissertations in China, 1989-2000, Tourism Geographies, 4(2): 148-152.

Baytok, A., Poyraz, M. ve Pelit, E. (2019). Turizm İşletmeciliği Alanında Yapılan Yüksek Lisans Tezlerinin Değerlendirilmesi: Afyon Kocatepe Üniversitesi Örneği, Afyon Kocatepe Üniversitesi Sosyal Bilimler Dergisi, 21(1): 287-305.

Bozkurt Çetinkaya, Ö. ve Çetin, A. (2016). Girişimcilik ve Kalkınma Dergisi'nin Bibliyometrik Analizi, ÇOMÜ Girişimcilik ve Kalkınma Dergisi, 11(2): 229-263.

Bull, C., Hoose, J. and Wheet, M. (2003). Introduction to Leisure Studies, Essex: Prentice Hall.

Buzlu, Ö M. (2015). Rekreasyon Araştırmaları ve Rekreasyon Bölümleri için Araştırma ve Müfredat Kapsamı Önerisi: Bilimetrik Bir Çalı̧ma, Mersin Üniversitesi Sosyal Bilimler Enstitüsü,Yüksek Lisans Tezi, Mersin.

Cevizkaya, G., İlsay, S. ve Avcıkurt, C. (2014). Turizm Alan Yazınında Engelliler ile İlgili Çalışmaların Bibliyometrik Profili (2000-2013), Gazi Üniversitesi Turizm Fakültesi Dergisi, 2: 101108. 
Cheng, M., Edwards, D., Darcy, S. and Redfern, K. (2018). A Tri-Method Approach to A Review of Adventure Tourism Literature: Bibliometric Analysis, Content Analysis, and A Quantitative Systematic Literature Review, Journal of Hospitality \& Tourism Research, 42(6): 997-1020.

Crossan, M. M. and Apaydin, M. (2010). A Multi-Dimensional Framework of Organizational Innovation: A Systematic Review of The Literature, Journal of Management Studies, 47(6): 11541191.

Currell, S. (2010). The March of Spare Time: The Problem and Promise of Leisure in The Great Depression, Philadelphia: University of Pennsylvania Press.

Çetinkaya, G. (2011). Türkiye'de Rekreasyon Alanında Yapılan Lisansüstü Tezlerin İncelenmesi (1985 - 2010 Dönemi), E-Journal of New World Sciences Academy, 6(1): 13-24.

Çiçek, D. ve Kozak, N. (2012). Anatolia: Turizm Araştırmaları Dergisi'nde Yayımlanan Hakem Denetimli Makalelerin Bibliyometrik Profili, Türk Kütüphaneciliği, 26(4): 734-756.

Demirbulat, Ö. G. ve Dinç, N. T. (2017). Sürdürülebilir Turizm Konulu Lisansüstü Tezlerin Bibliyometrik Profili, Seyahat ve Otel İşletmeciliği Dergisi, 14(2): 20-30.

Dutt, B., Garg, K. J. and Bali, A. (2003). Scientometrics of The International Journal: Scientometrics, Scientometrics, 56(1): 81-93.

Ekiz, D. (2009). Bilimsel Araştırma Yöntemleri: Yaklaşım, Yöntem ve Teknikler, Ankara: Anı Yayıncilik.

Evren, S. and Kozak, N. (2014). Bibliometric Analysis of Tourism and Hospitality Related Articles Published in Turkey, Anatolia - An International Journal of Tourism and Hospitality Research, 25(1): 61-80.

Fairthorne, R. (1969). Empirical Hyperbolic Distributions (Bradford-Zipf-Mandelbrot) for Bibliometric Description and Prediction, Journal of Documentation, 25(4): 319-343.

Godbey, G. C., Caldwell, L. L., Floyd, M. and Payne, L. L. (2005). Contributions of Leisure Studies and Recreation and Park Management Research to The Active Living Agenda, American Journal of Preventive Medicine, 28(2): 150-158.

Goodall, M. R., Barry, J. and Westing, M. B. (1972). Public Administration Review: 1940 through 1969, Public Administration Review, 32(1): 52-57.

Hall, C. M. (1991). Tourism as the Subject of Post-Graduate Dissertations in Australia. Annals of Tourism Research, 18(3): 520-523.

Hall, C. M. (2011). Publishor Perish? Bibliometric Analysis. Journal Ranking and The Assesment of Research Quality in Tourism, Tourism Management, 32(1): 16-27.

Jafari, J. and Aaser, D. (1988). Tourism as the Subject of Doctoral Dissertations, Annals of Tourism Research, 15(3): 407-429.

Jamal, T., Smith, B. and Watson, E. (2008). Ranking, Rating and Scoring of Tourism Journals: Interdisciplinary Challenges and Innovations, Tourism Management, 29(1): 66-78.

Jogaratnam, G., Chon, K., McCleary, K., Mena, M. and Yoo, J. (2005). An Analysis of Institutional Contributors to Three Major Academic Tourism Journals: 1992-2001, Tourism Management, 26(5): 641-648.

Kalkınma Bakanlığı. (2015a). VI. Beş Yıllık Kalkınma Planı. http://www.kalkinma.gov.tr/Lists/Kalknma\%20Planlar/Attachments/4/plan6.pdf. Erişim Tarihi: 30.12.2019. 
Kalkınma Bakanlı̆̆ı $\quad$ (2015b). VII. Beş $\quad$ Yıllık Kalkınma Planı. http://www.kalkinma.gov.tr/Lists/Kalknma\%20Planlar/Attachments/3/plan7.pdf. Erişim Tarihi: 30.12.2019.

Karasar, N. (1998). Bilimsel Araştırma Yöntemi-Kavramlar, Ilkeler, Teknikler, Ankara: Nobel Yayıncilik.

Kızanlıklı, M. M. (2014). Türkiye'deki Yükseköğretim Kurumlarında Rekreasyon Eğitiminin Yapis1, International Journal of Sport Culture and Science, 2(Special Issue 1): 46-60.

Kim, Y., Savage, K. S., Howey, R. M. and Van Hoof, H. B. (2009). Academic Foundations for Hospitality and Tourism Research: A Reexamination of Citations, Tourism Management, 30(5): 752-758.

Koç, E. and Boz, H. (2014). Triangulation in Tourism Research: A Bibliometric Study of Top Three Tourism Journals, Tourism Management Perspectives, 12: 9-14.

Kozak, M. (2015). Bilimsel Araştırma: Tasarım, Yazım ve Yayım Teknikleri, (2. Bask1), Ankara: Detay Yayıncılik.

Kozak, N. (1994). Anatolia: Turizm Araştırmaları Dergisi'nde Yayımlanan Yazılar Üzerine Bir İnceleme, Anatolia: Turizm Araştırmaları Dergisi, 5 (Aralık): 22-33.

Köseoğlu, M. A., Rahimi, R., Okumuş, F. and Liu, J. (2016). Bibliometric Studies in Tourism, Annals of Tourism Research, 61: 180-198.

Lapa, Y. T., Köse, E. ve Günbayı, İ. (2018). Türkiye'de Yapılan Rekreasyon Araştırmaları: Sistematik Bir Derleme, Spor Bilimleri Dergisi, 29(2): 87-102.

Mckercher, B., Law, R. and Lam, T. (2006). Rating Tourism and Hospitality Journals, Tourism Management, 27(6): 1235-1252.

Metin, C. T. (2013). Boş Zaman Literatürünün Dünyadaki Gelişimi: Leisure Science Dergisinde Yayımlanan Makaleler Üzerine Bir İnceleme, Anadolu Üniversitesi Sosyal Bilimler Enstitüsü, Yüksek Lisans Tezi, Eskişehir.

Meyer-Arendt, K. J. (2000). Commentary: Tourism Geography as The Subject of North American Doctoral Dissertations and Master's Theses, 1951-98, Tourism Geographies: An International Journal of Tourism Space, Place and Environment, 2: 140-156.

Meyer-Arendt, K. J. and Justice, C. (2002). Tourism as The Subject of North American Doctoral Dissertations, 1987-2000, Annals of Tourism Research, 29: 1171-1174.

Miller, A. C. ve Serzan, S. L. (1984). Criteria for Identifying A Refereed Journal, The Journal of Higher Education, 55(6): 673-699.

Nunkoo, R., Smith, S. L. and Ramkissoon, H. (2013). Residents' Attitudes to Tourism: A Longitudinal Study of 140 Articles From 1984 to 2010, Journal of Sustainable Tourism, 21(1): 5-25.

Okubo, Y. (1997). Bibliometric Indicators and Analysis of Research Systems: Methods and Examples, OECD Science, Technology and Industry Working Papers, Paris: OECD Publishing.

Okumuş, B., Köseoğlu, M. A. and Ma, F. (2018). Food and Gastronomy Research in Tourism and Hospitality: A Bibliometric Analysis, International Journal of Hospitality Management, 73: 64-74.

Özdamar, K., Odabaşı, Y., Hoşcan, Y., Bir, A. A., İftar, G. ve Uzuner, Y. (1999). Sosyal Bilimlerde Araştırma Yöntemleri, (Ed. A. A. Bir), Eskişehir: Anadolu Üniversitesi Yayınları. 
Özel, Ç. H. ve Kozak, N. (2012). Turizm Pazarlaması Alanının Bibliyometrik Profili (2000-2010) ve Bir Atıf Analizi Çalışması, Türk Kütüphaneciliği, 26(4): 715-733.

Özel, Ç. H., Yersüren, S. ve Çiftçi, F. (2018). Postmodern Klanlarda Yer Alan Turistlerin Güdüleri: Otostoprail Türkiye Örneği, Bolu Abant İzzet Baysal Üniversitesi Sosyal Bilimler Enstitüsü Dergisi, 18(2): 207-234.

Palmer, A. L., Sese, A. and Montaño, J. J. (2005). Tourism and Statistics: Bibliometric Study 19982002, Annals of Tourism Research, 32(1): 167-178.

Pritchard, A. (1969). Statistical Bibliography or Bibliometrics?, Journal of Documentation, 25: 348349.

Raisig, L. M. (1962). Statistical Bibliography in the Health Sciences, Bulletin of the Medical Library Association, 50(3): 450-461.

Rogerson, C. M. and Rogerson, J. M. (2011). Tourism Research Within The Southern African Development Community: Production and Consumption in Academic Journals, 2000-2010. Tourism Review International, 15(1-2): 213-224.

Rojek, C., Shaw, S. M. and Veal, A. J. (2006). Introduction: Process and Content. A handbook of Leisure Studies (1-21 içinde), London: Palgrave Macmillan.

Roy, B. S. and Basak, M. (2013). Journal of Documentation: A bibliometric Study, Library Philosophy and Practice, 1: 1-10.

Sağcan, M. (1986). Rekreasyon ve Turizm, İzmir: Cumhuriyet Kitabevi.

Sanchez, A. D., Del Rio, M. D. L. C. and Garcia, J. A. (2017). Bibliometric Analysis of Publications on Wine Tourism in The Databases Scopus and WoS, European Research on Management and Business Economics, 23(1): 8-15.

Schrader, A. M. (1981). Teaching Bibliometrics, Library Trends, 30(6): 151-172.

Sengupta, I. N. (1992). Bibliometrics, Informetrics, Scientometrics and Librametrics: An Overview, LIBRI, 42(2): 75-98.

Sevinç, B. (2001). Türkiye'de Lisansüstü Eğitim Uygulamaları, Sorunlar ve Öneriler, Ankara Üniversitesi Eğitim Bilimleri Fakültesi Dergisi, 34(1-2): 125-137.

Seymen, O., Maltepe, S., Çonoğlu, S., Yılmaz, Ö. G., Şahin, B., Tetik, N., Köroğlu, Ö. ve Akyol, G. (2009). Türkiye'de Yayımlanan Sosyal Bilimler Enstitüsü Dergilerinin Profili: Marmara ve Ege Bölgesi Örneği. Balıkesir Üniversitesi Sosyal Bilimler Enstitüsü Dergisi, 12(22): 281-301.

Shivers, J. S. and DeLisle, L. J. (1997). The Story of Leisure: Context, Concepts and Current Controversy, Illinois: Human Kinetics Publishers.

Sökmen, C. ve Özkanlı, O. (2018). Gastronomi Turizmi Alanyazının Gelişimi: Journal of Tourism and Gastronomy Studies Dergisinde Yayımlanan Makaleler Üzerine Bir İnceleme, Journal of Tourism and Gastronomy Studies, 6(2): 99-127.

Sünnetçioğlu, A., Yalçınkaya, P., Olcay, M. ve Mercan, Ş. O. (2017). Turizm Alanında Yazılmış Olan Gastronomiye İlişkin Tezlerin Bibliyometrik Profili, Journal of Tourism and Gastronomy Studies, 5(2): 345-354.

Şahin, S. ve Acun, A. (2015). Turist Rehberliği Alanının Bibliyometrik Profili (Ulusal Turizm Kongreleri Bildirileri), Balıkesir Üniversitesi Sosyal Bilimler Enstitüsü Dergisi, 18(34): 213-234. 
Şakar, G. D. ve Cerit, A. G. (2013). Uluslararası Alan İndekslerinde Türkiye Pazarlama Yazını: Bibliyometrik Analizler ve Nitel Bir Araştırma, Atatürk Üniversitesi İktisadi ve İdari Bilimler Dergisi, 27(4): 37-62.

Tayfun, A., Küçükergin, F. N., Aysen, E., Eren, A. ve Özekici, Y. K. (2016). Turizm Alanında Yazılan Lisansüstü Tezlere Yönelik Bibliyometrik Bir Analiz, Gazi Üniversitesi Turizm Fakültesi Dergisi, 1(1): 50-69.

Tranfield, D., Denyer, D. and Smart, P. (2003). Towards a Methodology for Developing EvidenceInformed Management Knowledge By Means Of Systematic Review, British Journal of Management, 14(3): 207-222.

Türe, H. ve Ersoy, F. A. (2015). Sosyal Bilgiler Öğretmenlerinin Hoşgörü Eğitimine Bakışı ve Hoşgörü Eğitimine İlişkin Uygulamaları, Anadolu Journal of Educational Sciences International, 5(1): 57-87.

Tütüncü, Ö. (2008). Rekreasyon Yönetimine Yönelik Üniversite Düzeyinde Bir Müfredat Önerisi, Anatolia: Turizm Araştırmaları Dergisi, 19(1): 93-103.

Williams, D. J. (2006). Forensic Leisure Science: A New Frontier for Leisure Scholars, Leisure Sciences, 28(1): 91-95.

Yeşilyurt, H. ve Yeşilyurt, C. (2013). Boş Zaman ve Rekreasyona Yönelik Dergilerde Yayınlanan Makalelerin Bibliyometrik Analizi, II. Rekreasyon Araştırma Kongresi Bildiri Kitabı (31 Ekim-03 Kasım 2013, Aydın), 671-675.

Yetiş, A. Ş. ve Çokal, Z. (2018). Kış Turizmi Alanında Yayımlanan Makalelerin Bibliyometrik Profili, Journal of Recreation and Tourism Research, 5(1): 38-52.

Zencir, E. ve Kozak, N. (2012). Sosyal Bilimler Enstitü Dergilerinde Yayımlanan Turizm Makalelerinin Bibliyometrik Profili (2000-2010), VI. Lisansüstü Turizm Öğrencileri Araştırma Kongresi Bildiri Kitabı (12-15 Nisan 2012, Antalya), 673-685.

Zorba, E. (2008). Türkiye'de Rekreasyona Bakış Açısı ve Gelişimi, Gazi Haber Dergisi, 52-55. 